\title{
TINGKAT KECEMASAN KELUARGA PASIEN SAAT MENUNGGU ANGGOTA KELUARGA YANG DIRAWAT DI RUANG ICU RUMAH SAKIT ISLAM IBNU SINA PEKANBARU
}

\author{
Neneng Astuti, Yesi Sulastri \\ Program Studi DIII Keperawatan, Fakultas MIPA dan Kesehatan, Universitas Muhammadiyah Riau \\ Jln. K.H. Ahmad Dahlan No.88 Sukajadi Pekanbaru \\ Telp. (0761) 35008, 20497, Fax. (0761) 36912, e-mail: go_ners@yahoo.com
}

\begin{abstract}
ABSTRAK
Kecemasan dapat timbul secara otomatis akibat dari stimulus internal dan eksternal yang berlebihan sehingga melampaui kemampuan individu untuk menanganinya maka timbul cemas. dampak dari kecemasan akan mempengaruhi pikiran dan motivasi sehingga keluarga tidak mampu mengembangkan peran dan fungsinya yang bersifat mendukung terhadap proses penyembuhan dan pemulihan anggota keluarganya yang sedang dirawat di ruang ICU (Keltner, 1995; Sibuea, 2010). Tujuan penelitian ini adalah untuk mengetahui gambaran tingkat kecemasan keluarga pasien saat menunggu anggota keluarga yang dirawat di ruang ICU Rumah Sakit Islam Ibnu Sina Pekanbaru. Penelitian ini menggunakan METODOLOGI PENELITIAN deskriptif kuantitatif, pengambilan sampel penelitian menggunakan teknik aksidental sampling, pengumpulan data dilakukan dengan menggunakan instrumen HARS (Hamilton Anxiety Rating Scale). Hasil penelitian dari 40 responden, secara umum mayoritas responden merasakan kecemasan sedang dengan persentase sebesar $72,5 \%$, sebagian kecil responden merasakan kecemasan ringan dengan persentase $15 \%$ dan sebagian kecil responden merasakan kecemasan berat dengan persentase $12,5 \%$. Berdasarkan hasil penelitian, maka penulis menyarankan agar bidang keperawatan membentuk divisi khusus yang bertugas menjadi konsultan bagi keluarga pasien yang mengalami kecemasan di ruang tunggu ICU, yang berguna untuk mengantisipasi agar rasa cemas keluarga tidak sampai ke tingkat berat dan panik.
\end{abstract}

Kata Kunci: Tingkat Kecemasan, Keluarga Pasien, Intensive Care Unit

\section{PENDAHULUAN}

Kecemasan merupakan respon individu terhadap suatu keadaan yang tidak menyenangkan yang dialami oleh setiap mahluk hidup dalam kehidupan sehari-hari. Kecemasan merupakan pengalaman subjektif dari individu dan tidak dapat diobservasi secara langsung serta merupakan suatu keadaan emosi tanpa objek yang spesifik (Suliswati, 2005).

Sebuah keluarga merupakan unit dasar dari masayarakat dimana anggotanya mempunyai suatu komitmen untuk memelihara satu sama lain baik secara emosi maupun fisik. Sebuah keluarga dapat dipandang sebagai sistem terbuka. Suatu perubahan atau gangguan pada salah satu bagian dari sistem dapat mengakibatkan perubahan atau gangguan dari seluruh sistem. Stres atau cemas yang dihadapi dan dialami oleh salah satu anggota keluarga mempengaruhi seluruh keluarga. Cemas disebabkan oleh karena krisis situasi, tidak terpenuhinya kebutuhan, perasaan tidak berdaya dan kurang kontrol pada situasi kehidupan (Surtydewi, 2007).

Kondisi sakit tidak dapat dipisahkan dari peristiwa kehidupan. Klien dan keluarganya harus menghadapi berbagai perubahan yang terjadi akibat kondisi sakit dan pengobatan yang dilaksanakan. Keluarga umumnya akan mengalami perubahan perilaku dan emosional, setiap orang mempunyai reaksi yang berbedabeda terhadap kondisi yang dialami. Penyakit yang berat, terutama yang dapat mengancam kehidupan, dapat menimbulkan perubahan perilaku yang lebih luas, kecemasan, syok, penolakan, marah. Hal tersebut merupakan respon umum yang disebabkan oleh stres (Potter, 2005).

Kecemasan dapat timbul secara otomatis akibat dari stimulus internal dan eksternal yang berlebihan sehingga melampaui kemampuan individu untuk menanganinya maka timbul cemas. 
Dampak dari kecemasan akan mempengaruhi pikiran dan motivasi sehingga keluarga tidak mampu mengembangkan peran dan fungsinya yang bersifat mendukung terhadap proses penyembuhan dan pemulihan anggota keluarganya yang sedang dirawat di ruang ICU (Keltner, 1995; Sibuea, 2010). Anggota keluarga akan mengalami kecemasan saat menghadapi salah satu anggota keluarga yang dirawat, peneliti yang saat ini bertugas di ruang ICU akan meneliti sejauh mana tingkat kecemasan keluarga pasien saat menunggu anggota keluarga yang dirawat di ruang ICU.

\section{METODOLOGI PENELITIAN}

Penelitian ini menggunakan METODOLOGI PENELITIAN deskriptif kuantitatif, yaitu untuk mendapatkan gambaran tingkat kecemasan keluarga pasien saat menunggu di ruang Intensive Care Unit Rumah Sakit Islam Ibnu Sina Pekanbaru. Pengambilan sampel penelitian menggunakan teknik accidental sampling pada keluarga pasien yang berkunjung selama bulan Februari 2011, dengan jumlah sampel seluruhnya adalah 40 responden. Pengumpulan data dilakukan dengan menggunakan instrumen HARS (Hamilton Anxiety Rating Scale). Cara penilaian penggunaan instrumen dalam penelitian ini dengan memberikan skor 0-4 pada masing-masing pertanyaan, yaitu: skor 0 (tidak ada gejala/keluhan); skor 1 (gejala ringan); skor 2 (gejala sedang); skor 3 (gejala berat), dan skor 4 (gejala berat sekali/panik) (Hawari, 2001). Analisis data dilakukan dengan menggunakan derajat tingkat kecemasan, yaitu: <14 (tidak cemas); 14-20 (kecemasan ringan); 21-27 (kecemasan sedang); 28-41 (kecemasan berat); dan 42-56 (kecemasan berat sekali/panik) (Nursalam (2008).

\section{HASIL DAN PEMBAHASAN}

Hasil penelitian melalui pengumpulan data yang diikuti oleh 40 responden, yaitu keluarga pasien yang sedang menunggu anggota keluarga yang dirawat di ruang Intensive Care Unit Rumah Sakit Islam Ibnu Sina Pekanbaru dari tanggal 0227 Februari 2011.
Tabel 1. Distribusi Frekuensi Karakteristik

Responden di Ruang Tunggu Intensive Care Unit Rumah Sakit Islam Ibnu Sina Pekanbaru $(n=40)$

\begin{tabular}{lll}
\hline Karakteristik Responden & f & \% \\
\hline Umur (tahun) & & \\
a. $19-34$ & 17 & 42,5 \\
b. $35-50$ & 9 & 22,5 \\
c. $51-66$ & 14 & 35,0 \\
\hline Jenis Kelamin & & \\
a. Laki-laki & 15 & 37,5 \\
b. Perempuan & 25 & 62,5 \\
\hline Pendidikan & & \\
a. SD & 5 & 12,5 \\
b. SMP & 6 & 15,0 \\
c. SMA & 18 & 45,0 \\
d. PT & 11 & 27,5 \\
\hline Pekerjaan & & \\
a. PNS & 3 & 7,5 \\
b. Pegawai Swasta & 14 & 35,0 \\
c. Wiraswasta & 10 & 25,0 \\
d. Petani & 2 & 5,0 \\
e. IRT & 11 & 27,5 \\
\hline
\end{tabular}

Berdasarkan tabel 1. di atas, dapat dilihat bahwa mayoritas responden berumur 19-34 tahun berjumlah 17 responden (42,5\%), jenis kelamin mayoritas adalah perempuan berjumlah 25 responden $(62,5 \%)$, pendidikan terakhir mayoritas SMA berjumlah 18 responden $(45 \%)$, dan mayoritas bekerja sebagai pegawai swasta berjumlah 14 responden $(35,0 \%)$.

Tabel 2. Distribusi Frekuensi Tingkat Kecemasan Responden di Ruang Tunggu Intensive Care Unit Rumah Sakit Islam Ibnu Sina Pekanbaru $(n=40)$.

\begin{tabular}{lll}
\hline Tingkat Kecemasan & $\mathbf{f}$ & $\mathbf{\%}$ \\
\hline Tidak cemas & - & - \\
Kecemasan ringan & 6 & 15,0 \\
Kecemasan sedang & 29 & 72,5 \\
Kecemasan berat & 5 & 12,5 \\
Kecemasan berat & - & - \\
$\quad$ sekali/panik & & \\
\hline
\end{tabular}

Berdasarkan tabel 2. di atas, dapat dilihat bahwa mayoritas responden merasakan kecemasan sedang berjumlah 29 responden $(72,5 \%)$, sebagian kecil responden merasakan kecemasan ringan berjumlah 6 responden (15\%) 
dan sebagian kecil responden merasakan kecemasan berat berjumlah 5 responden (12,5\%).

Hasil penelitian di atas menunjukkan perbedaan dengan hasil penelitian yang dilakukan oleh Sibuea (2010), yang meneliti tentang tingkat kecemasan keluarga pasien saat menunggu anggota keluarga dirawat di ruang ICU Rumah Sakit Immanuel Bandung, menyimpulkan bahwa dari 30 responden hampir seluruh responden merasakan cemas berat yang berjumlah 25 responden (83\%), sebagian kecil responden merasakan cemas sedang berjumlah 3 responden (10\%) dan sebagian kecil responden mengalami panik berjumlah 2 responden (7\%).

Respon kecemasan yang muncul pada keluarga pada pasien yang menunggu anggota keluarga yang dirawat di ruang ICU sangat berbeda untuk tiap individu, sesuai dengan pernyataan responden yang menunjukkan bahwa ada yang merasa sedih, berdebar-debar, dan kesulitan tidur, semua ini merupakan tanda dari seseorang yang mengalami kecemasan tingkat sedang, tapi ada juga keluarga yang mengalami tingkat kecemasan berat dengan ditandai bingung, gelisah, sulit konsentrasi, takut anggota keluarga meninggal atau takut kehilangan keluarga. Respon kecemasan yang muncul pada keluarga pada pasien yang dirawat di ruang ICU termasuk rentang respon yang adaptif dan belum mengarah ke respon mal adaptif. Hal ini disebabkan karena mekanisme koping yang digunakan oleh keluarga dalam menghadapi suatu stressor sudah cukup baik dan dapat beradaptasi dengan segala permasalahan baik itu dari dalam maupun dari luar diri keluarga itu sendiri.

\section{KESIMPULAN}

Hasil penelitian di atas menunjukkan bahwa mayoritas responden merasakan kecemasan sedang berjumlah 29 responden (72,5\%), sebagian kecil responden merasakan kecemasan ringan berjumlah 6 responden (15\%) dan sebagian kecil responden merasakan kecemasan berat berjumlah 5 responden $(12,5 \%)$.

Berdasarkan hasil penelitian di atas, maka diharapkan kepada bidang keperawatan untuk membentuk divisi khusus yang bertugas menjadi konsultan bagi keluarga pasien yang mengalami kecemasan di ruang tunggu ICU, yang berguna untuk mengantisipasi agar rasa cemas keluarga tidak sampai ke tingkat berat dan panik.

\section{DAFTAR PUSTAKA}

Hawari, D. (2001). Manajemen stress, cemas dan depresi. Jakarta: Balai Penerbit FK UI.

Nursalam. (2008). Konsep dan penerapan metodologi penelitian ilmu keperawatan: pedoman skripsi, tesis dan instrumen penelitian keperawatan. Jakarta: Salemba Medika.

Potter, P. A. (2005). Buku ajar fundamental keperawatan dan praktik. Edisi 4. Jakarta: EGC.

Sibuea E. (2010). Tingkat kecemasan keluarga pasien saat menunggu anggota keluarga dirawat di ruang ICU Rumah Sakit Immanuel Bandung. http://www.rsimmanuel.com/index.php?opt ion $=$ com_content $\&$ view $=$ article $\& i d=133 \mathrm{am}$ $\mathrm{p} ;$ Itemid $=133$.

Suliswati. (2005). Konsep dasar keperawatan kesehatan jiwa. Jakarta: EGC.

Surtydewi, L. (2007). Peran unit stroke dalam tatalaksana stroke komprehensif. Jakarta: Balai Penerbit FK UI. 